\title{
TIMING AND CAUSE OF WATER LEVEL FLUCTUATIONS IN KLUANE LAKE, YUKON TERRITORY, OVER THE PAST 5000 YEARS
}

\author{
Janice Brahney* (Corresponding Author), Department of Earth Sciences, Simon Fraser \\ University, Burnaby, BC V5A 1S6, Canada
}

John J. Clague, Department of Earth Sciences, Simon Fraser University, Burnaby, BC V5A 1S6, Canada

Brian Menounos, Natural Resources and Environmental Studies Institute and Geography Program, University of Northern British Columbia, Prince George, BC V2N 4Z9, Canada

Thomas, W.D. Edwards, Department of Earth and Environmental Sciences, University of Waterloo, Waterloo, ON N2L 3G1, Canada

*Current address: Department of Geological Sciences, University of Colorado at Boulder, Boulder, CO., 80309, USA Janice.brahney@ colorado.edu 


\begin{abstract}
We reconstructed late Holocene fluctuations of Kluane Lake in Yukon Territory from variations in bulk physical properties and carbon and nitrogen elemental and isotopic abundances in nine sediment cores. Fluctuations of Kluane Lake in the past were controlled by changes in climate and glaciers, which affected inflow of Slims and Duke rivers, the two largest sources of water flowing into the lake. Kluane Lake fluctuated within a narrow range, at levels about $25 \mathrm{~m}$ below the present datum, from about 5000 to 1300 cal yr BP. Low lake levels during this interval are probably due to southerly drainage of Kluane Lake to the Pacific Ocean, opposite the present northerly drainage to Bering Sea. Slims River, which today is the largest contributor of water to Kluane Lake, only rarely flowed into the lake during the period 5000 to $1300 \mathrm{cal} \mathrm{yr} \mathrm{BP}$. The lake rose 7-12 m between 1300 and $900 \mathrm{cal}$ yr BP, reached its present level around AD 1650, and within a few decades had risen an additional $12 \mathrm{~m}$. Shortly thereafter, the lake established a northern outlet and fell to near its present level.
\end{abstract}

Keywords: paleolimnology, sedimentology, carbon isotopes, nitrogen isotopes, magnetic susceptibility, Kluane Lake, Yukon Territory 


\section{Introduction}

Lakes are sensitive to climate, and their levels may change quickly if climate change alters their watershed hydrology. Glacierized basins are particularly sensitive to climatically driven hydrological changes, because prolonged warming can release stored water from snow and ice as well as large amounts of sediment that can alter catchment drainage (Gilbert and Desloges, 1987). Here we use the physical properties and organic geochemistry of sediment cores to infer paleo-lake depth and possible causes of lakelevel changes in Kluane Lake, the largest lake in Yukon Territory, Canada (Figure 1).

Physical, chemical, and biological properties of lake sediments provide information on past conditions of the lake, its catchment and local and regional climate, and other aspects of the environment. However, because no single environmental proxy is definitive, a multi-proxy approach must be used to accurately reconstruct the history and past environments of a lake. Here we use a multi-proxy approach to infer changes, during late Holocene time, in the depth and area of Kluane Lake. We demonstrate an interplay between changes in lake level and Little Ice Age activity of Kaskawulsh Glacier, one of the largest valley glaciers in the St. Elias Mountains (Figure 1). We also show that Kluane River, which presently discharges from Kluane Lake to Bering Sea, has existed for only three centuries. Before about AD 1700, Kluane Lake was probably a closed basin or it drained south to the Pacific Ocean.

We infer changes in the depth of Kluane Lake, in part, from sediment properties, including grain size, that reflect depositional energy and proximity to the lakeshore. A gradual coarsening of sediment may signal a decrease in water depth. In modern Kluane Lake, clean sand occurs to a depth of $5 \mathrm{~m}$, below which it grades into silt (Rampton and 
Shearer, 1978). We assume that this relationship has existed in the past and use it to aid in reconstructing former lake levels. Also, as lacustrine sediment becomes coarser, its water content generally decreases; the change is also accompanied by an increase in dry density (Menounos, 1997). Increased organic content also influences these properties by increasing pore space and water content, and decreasing density. A reduction in water content and an increase in dry density may indicate a transition from organic-rich sediments to dominantly clastic sediments.

We also use sediment geochemistry to infer past conditions in Kluane Lake. Organic matter provenance, productivity, nutrient availability, and depositional conditions can be inferred from carbon and nitrogen concentrations and from isotopic and elemental ratios. We use carbon isotopes to infer organic matter sources, nutrient utilization, and dissolved inorganic carbon (DIC) cycling. In particular, $\delta^{13} \mathrm{C}$ is useful for recognizing terrestrial shifts in major plant species with different metabolisms $\left(\mathrm{C}_{3}\right.$ versus $\mathrm{C}_{4}$ ) (Meyers and Teranes, 2001). Although the dissolved inorganic carbon source is the primary determinant of lacustrine sedimentary $\delta^{13} \mathrm{C}$ values, increased nutrient utilization can result in Rayleigh fractionation of the available DIC (Meyers and Teranes, 2001). When productivity increases, the DIC reserve of ${ }^{12} \mathrm{C}$ in the epilimnion is depleted and ${ }^{13} \mathrm{C}$ is used in greater amounts. This effect is manifested in the sediment record as a positive excursion in the carbon isotope ratio $\left(\delta^{13} \mathrm{C}\right)$.

Nitrogen may show a similar isotopic increase due to Rayleigh fractionation at times of greater productivity. $\delta^{15} \mathrm{~N}$ can also be used to distinguish between nitrogen derived from aquatic and terrestrial sources. Terrestrial plants use an atmospheric source of nitrogen $(0 \%)$, and recycling of nitrogen in aquatic systems tends to systematically 
increase $\delta^{15} \mathrm{~N}$ values. An additional mechanism for producing positive $\delta^{15} \mathrm{~N}$ excursions is diagenetic release of isotopically light $\mathrm{N}_{2}$ gases released during nitrification under reducing conditions (Talbot, 2001).

We use the ratio of $\mathrm{C} / \mathrm{N}$ in Kluane Lake sediments to distinguish between inorganic and aquatic organic matter (Meyers and Teranes, 2001). C/N ratios are generally larger (> 20) for terrestrial plants because they contain proportionally more carbon-rich structural materials. Protein-rich algal material grown under optimum nutrient conditions have $\mathrm{C} / \mathrm{N}$ ratios of 4-10 (Meyers and Teranes, 2001). In contrast, under nutrient-limited conditions, the $\mathrm{C} / \mathrm{N}$ ratio of algal material can increase to values within the terrestrial range (Healy and Hendzel, 1979; Hecky et al., 1993).

We identify dominant organic matter types, and recognize diagenic effects on sedimentary organic matter, by regressing elemental carbon against nitrogen. Intercepts of the regression lines above zero indicate the presence of inorganic-bound elements. An excess of nitrogen in Kluane Lake sediments may indicate the presence of inorganicbound nitrogen, probably resulting from organic matter degradation and release of $\mathrm{NH}_{4}^{+}$. This ion can bind to clay in the sediments, decreasing the $\mathrm{C} / \mathrm{N}$ ratio. The intercept of the $\mathrm{C}-\mathrm{N}$ regression models can be used to correct the $\mathrm{C} / \mathrm{N}$ ratio of the organic-bound elements (Talbot, 2001).

\section{Study site}

Kluane Lake $\left(409 \mathrm{~km}^{2}\right)$ is located within Shakwak Trench in southwest Yukon Territory (Figure 1; Natural Resources Canada, 2003). The lake is bordered by the Ruby Ranges on the east and the Kluane Ranges, which are part of the St. Elias Mountains, on 
the west. The surface elevation of Kluane Lake fluctuates 1-2 m annually, due mainly to changes in the flow of Slims River, which is its principal source of surface water. Lake level rises in summer when Slims River discharge is high and falls during autumn prior to freeze-up.

Large amounts of clay, silt, and sand are discharged into Kluane Lake by Slims River. A conspicuous turbid overflow plume covers much of the southernmost part of the lake during the summer melt season, and turbidity currents transport fine sediment far from the Slims River delta front. Other significant sediment sources include Gladstone River, Silver Creek, and several ephemeral streams that flow from the Kluane Range west of the lake (Figure 1).

Previous work has shown that the level of Kluane Lake has changed by several tens of metres during the late Holocene. Bostock (1969) and Clague (1981) noted drowned trees at the perimeter of the lake that indicate the lake was lower in the recent past. They also described beaches and mats of driftwood up to $12 \mathrm{~m}$ above present lake level. A lake level more than $50 \mathrm{~m}$ below present was proposed by Rampton and Shearer (1978) based on their discovery of an inferred 2000-year-old soil layer in a sediment core near the south end of the lake. Clague et al. (2006) used dendrochronology to show the lake reached its most recent high stand, $+12 \mathrm{~m}$ above its modern elevation, during the late seventeenth century. They attributed this rise to the climactic Little Ice Age advance of Kaskawulsh Glacier, which blocked the former southerly drainage route of the lake. Blockage of the southerly outlet created Slims River, which flowed into Kluane Lake and raised its level $12 \mathrm{~m}$ to the lowest point on Duke River fan at the north end of the basin. The lake then began to overflow to the north across the fan and into the Yukon River 
watershed, establishing Kluane River and redirecting drainage from the Pacific Ocean to Bering Sea.

Kaskawulsh Glacier advanced several times during the late Holocene prior to the Little Ice Age (Borns and Goldthwait, 1966; Denton and Stuiver, 1966; Denton and Karlén, 1977). Source-area fingerprinting of Kluane Lake sediments suggests that meltwater from the glacier entered the lake via Slims River during at least two of these advances (Brahney et al., 2007). Duke River, which presently bypasses Kluane Lake, also flowed into the lake on at least two occasions during the late Holocene (Brahney et al., 2007).

\section{Field and Laboratory Methods}

We conducted an acoustic sub-bottom survey of Kluane Lake with a Datasonics Chirp II system in July 2004 to provide information on bathymetry of the lake and the character and structure of its Holocene sediment fill. About $180 \mathrm{~km}$ of lines were collected along thirty oblique transects and one axial transect. Coring locations were chosen on the basis of this survey.

We collected 13 percussion cores in July 2004, 11 from Kluane Lake, one from Cultus Bay, and one from Grayling Lake (Figure 2). Cultus Bay is almost completely separated from Kluane Lake by a narrow spit, and Grayling Lake is an adjacent isolated basin. We transported the cores to the University of Northern British Columbia in Prince George, British Columbia. There we described and photographed them and analyzed them at a high resolution for water content, bulk density, magnetic susceptibility, and organic content. Samples from cores 26 and 36 were analyzed for grain size using a 
Malvern 2000G Mastersizer. Magnetic susceptibility was measured with a Bartington MS2B sensor. Water content, bulk density, and loss on ignition were determined by drying in an oven at $105^{\circ} \mathrm{C}$ and $550^{\circ} \mathrm{C}$.

We measured nitrogen and carbon isotopes in samples of treated sediments from cores 10, 26, and 36 at the University of Waterloo in Waterloo, Ontario. Samples were washed in $10 \% \mathrm{HCl}$ and rinsed with distilled water until neutral. Freeze-dried sediments were then sieved through a $500 \mu \mathrm{m}$ mesh to remove coarse material and potential terrestrial organic matter. The remaining sediment was analyzed using an Isochrom EACFIRMS continuous-flow isotope mass spectrometer and compared to the Vienna PeeDee Belemnite (V-PDB) for carbon and the atmospheric standard for nitrogen. Standard deviations for reference materials are $\pm 0.2 \%$ for carbon and $\pm 0.3 \%$ for nitrogen. We tested for the presence of elements not bound in organic matter, which can influence the $\mathrm{C} / \mathrm{N}$ ratio, with scatter plots of elemental $\mathrm{C}$ and $\mathrm{N}$. Elemental abundances were used to correct $\mathrm{C} / \mathrm{N}$ values. Loss on ignition was used to determine organic content in cores 13 and 31 .

Plant macrofossils were dated by the AMS radiocarbon technique at Beta Analytic and IsoTrace (University of Toronto). Additional dating control is provided by the White River tephra, which is about 1150 years BP (Clague et al., 1995) and is present in most cores. The tephra, ${ }^{14} \mathrm{C}$ ages on in situ roots, forest litter, and detrital wood in cores, and tree-ring ages for the rise of Kluane Lake over the past 350 years (Clague et al., 2006) were used to estimate sedimentation rates and dates of major events recorded in the cores, including lake-level changes. Estimates of unit ages were refined by correlating shifts in geochemical proxies. 


\section{Results}

We subdivided cores into lithostratigraphic units based on sediment texture, colour, stratification, and shifts in carbon and nitrogen elemental abundances and isotopic values (Figures 3 and 4). Core stratigraphy is summarized in Table 1; radiocarbon and calibrated ages are presented in Table 2; calculated calendar ages, and sedimentation rates on which they are based, are presented in Table 3; and average sedimentation rates for lithostratigraphic units at all core sites are listed in Table 4. Relevant information and statistical results for select cores are outlined below.

\section{Core 36}

Core 36 was collected near the southeast end of Kluane Lake at a depth of $36 \mathrm{~m}$ (Figure 2). The core is $240 \mathrm{~cm}$ long and comprises five units (Figure 5, Table 1). Units 1, 2, and $3(240-97 \mathrm{~cm})$ consist of silt with black laminae up to $1 \mathrm{~mm}$ thick; units 1 and 3 have numerous black laminae and unit 2 has few of them. A piece of wood at $219 \mathrm{~cm}$ depth yielded a radiocarbon age of $3910 \pm 80{ }^{14} \mathrm{C}$ yr BP (4570-4090 cal yr BP; Table 2). The contact between units 3 and 4 is interfingering. Unit $4(96-66 \mathrm{~cm})$ consists of massive sand and silt, with White River tephra at $88 \mathrm{~cm}$. The contact with unit 5 is abrupt. Unit 5 is mainly clayey silt.

The slopes and intercepts of the best-fit lines of carbon-nitrogen plots indicate that the five units have different organic matter compositions. An F-test against the null hypothesis that all regressions are equal indicates that separate regressions are significantly different and improve the squared error $(p<0.01)$. The line that best fits the data from unit $1(\% \mathrm{~N}=0.05 \% \mathrm{C})$ has an $r^{2}$ of $0.70(p<0.01)$. The carbon-nitrogen plot 
separates unit 2 into two sections, $219-195 \mathrm{~cm}(\% \mathrm{~N}=0.07 \% \mathrm{C})$ and $193-157 \mathrm{~cm}(\% \mathrm{~N}=$ $0.07 \% \mathrm{C})$, with $r^{2}$ values of $0.78(p<0.01)$ and $0.92(p<0.001)$, respectively. The best-fit line for unit $3(\% \mathrm{~N}=0.06 \% \mathrm{C})$ has an $r^{2}$ of $0.96(p<0.001)$. The best-fit line for unit 4 $(\% \mathrm{~N}=0.1 \% \mathrm{C})$ has an $r^{2}$ of $0.85(p<0.001)$. The lowest correlation between $\mathrm{C}$ and $\mathrm{N}$ is for unit 5 data $\left(\% \mathrm{~N}=0.09 \% \mathrm{C} ; r^{2}=0.66, p<0.001\right)$.

Units 1 and 3 have $\mathrm{C} / \mathrm{N}$ ratios of 17-18 (Figure 5), whereas the $\mathrm{C} / \mathrm{N}$ ratios of the other three units are $10-12$. The $\mathrm{C} / \mathrm{N}$ ratio and $\% \mathrm{C}$ in units 1 through 4 are negatively correlated to $\delta^{13} \mathrm{C}\left(r^{2}=0.58, p<0.001\right.$ for $\mathrm{C} / \mathrm{N} ;\left(r^{2}=0.65, p<0.001\right.$ for $\left.\% \mathrm{C}\right) . \delta^{13} \mathrm{C}$ shows small step shifts through the core, with some variability in unit $5 . \delta^{13} \mathrm{C}$ and the $\mathrm{C} / \mathrm{N}$ ratio are positively correlated in unit $5\left(r^{2}=0.81, p<0.001\right)$.

\section{Core 10}

Core 10 was collected in $33 \mathrm{~m}$ of water on the east side of the lake, north of Cultus Bay (Figure 2). The core is $108 \mathrm{~cm}$ long and consists of five units (Figure 3; Table 1). Unit $1(108-92 \mathrm{~cm})$ and unit $2(91-69 \mathrm{~cm})$ are upward-fining, laminated silts. The contact between the two units is gradational. Unit 3 (68-36) and unit 4 (33-19) are separated by a 2-cm-thick layer of White River tephra $(35-33 \mathrm{~cm})$. Unit 4 is silt with several orange laminae. Unit $5(18-0 \mathrm{~cm})$ comprises silt with diffuse orange laminae.

The carbon-nitrogen plots show a systematic offset in unit 3 at $57-58 \mathrm{~cm}$ (Figures 6 and 7). An F-test indicates that separate regressions of unit 3 data above and below this level are significantly different and improve the squared error $(\mathrm{p}<0.01)$. The best-fit lines for the data from 108 to $92 \mathrm{~cm}(\% \mathrm{~N}=0.06 \% \mathrm{C})$ and 91 to $69 \mathrm{~cm}(\% \mathrm{~N}=0.9 \% \mathrm{C})$ have $r^{2}$ values of $0.70(p<0.001)$ and $0.83(p<0.001)$, respectively. The best-fit lines for data from 68 to $58 \mathrm{~cm}(\% \mathrm{~N}=0.06 \% \mathrm{C}+0.02)$ and 57 to $36 \mathrm{~cm}(\% \mathrm{~N}=0.07 \mathrm{C}+0.18)$ have $r^{2}$ values 
of $0.98(p<0.001)$ and $0.93(p<0.001)$, respectively; they indicate nitrogen excesses of 0.02 and 0.018 , respectively. Intercept values for these two units are an order of magnitude greater than the intercepts of all other units and are large enough to have an effect on the $\mathrm{C} / \mathrm{N}$ ratio. For this reason, $\mathrm{C} / \mathrm{N}$ ratios for these units were corrected using the nitrogen excess. The intervals from $32-19 \mathrm{~cm}$ and $18-0 \mathrm{~cm}$ plot together $(\% \mathrm{~N}=$ $0.013 C)$ and have an $r^{2}$ value of $0.86(p<0.001)$. When corrected for elemental excesses, $\mathrm{C} / \mathrm{N}$ variations in core 10 are similar to those in core 36 . Unit 1 and unit 3 in core 10 have high $\mathrm{C} / \mathrm{N}$ ratios, ranging from 14 to $19 . \mathrm{C} / \mathrm{N}$ ratios in the remainder of the core are lower $(9-12)$.

Carbon-13 increases slightly in unit 4 and then again in unit 5. A peak in $\delta^{13} \mathrm{C}$ in unit 5 correlates with a peak in $\mathrm{C} / \mathrm{N}$. As in core $36, \delta^{13} \mathrm{C}$ negatively correlates with $\% \mathrm{C}$ $\left(r^{2}=0.77, p<0.001\right.$ for units 1 through 4$)$. Valvata sincera sincera shells are present from the base of the core to $61 \mathrm{~cm}$ depth.

\section{Core 08}

Core 08 was collected near the east side of the lake, midway between Christmas and Cultus bays, at a depth of $25 \mathrm{~m}$ (Figure 2 and 3). It is $63 \mathrm{~cm}$ long and comprises four units (Figure 8). Material in the core catcher (unit 1) is coarse sand. Unit 2, from the base of the core to $34 \mathrm{~cm}$, is laminated fine to medium sand. Unit $3(33-17 \mathrm{~cm})$ interfingers with unit 3 and consists of laminated fine sand with distinct orange laminae. The contact between units 3 and 4 is sharp. Unit $4(16-0 \mathrm{~cm})$ comprises laminated silt with pale yellow beds $1-1.5 \mathrm{~cm}$ thick. We did not analyze core 08 for carbon and nitrogen, but its stratigraphy and sedimentology are important to our interpretation later in the paper. 


\section{Core 26}

Core 26 was collected in Cultus Bay in $14 \mathrm{~m}$ of water (Figure 2). The core is 180 cm long and consists of five units (Figure 4; Table 1). Unit 1, from the base of the core to $156 \mathrm{~cm}$ depth, is coarse sand with forest litter at $177 \mathrm{~cm}$. Its contact with unit 2 is sharp. Unit $2(155-140 \mathrm{~cm})$ consists of fine to medium sand and scattered plant detritus. Unit 3 $(139-53 \mathrm{~cm})$ is composed of organic silt with fine sand laminae. Several black streaks and laminations, roots in growth position, and plant detritus occur near the base of this unit. A piece of wood at $139 \mathrm{~cm}$ and another at $177 \mathrm{~cm}$ returned identical radiocarbon ages of $1180 \pm 40{ }^{14} \mathrm{C}$ yr BP (1180-980 cal yr BP; Table 2). Unit 4 (52-42 cm) consists of rhythmically laminated silt. Unit $5(41-0 \mathrm{~cm})$ is weakly laminated silt with scattered black spots and streaks. A sharply bounded bed with low organic content occurs at 37-39 cm depth.

Magnetic susceptibility increases in steps from 55 to $43 \mathrm{~cm}$ and from 40 to $37 \mathrm{~cm}$ due to the presence of reworked tephra (Figure 9). A lesser susceptibility peak also occurs at $73-67 \mathrm{~cm}$. Sediment density and $\delta^{13} \mathrm{C}$ are positively correlated with magnetic susceptibility, which peak at 73-67, 55-43, and 40-37 cm. Carbon-13 and \%C are negatively correlated, and $\delta^{13} \mathrm{C}$ is positively correlated with $\mathrm{C} / \mathrm{N}$. $\mathrm{C} / \mathrm{N}$ ratios are high in unit 4 , with peak values of $17 . \mathrm{C} / \mathrm{N}$ ratios are low and nearly constant in unit 5 , ranging from 10 to 11 . Percent $\mathrm{C}$ and $\mathrm{N}$ are highest in unit 5; they are highly correlated from 43 to $0 \mathrm{~cm}\left(r^{2}=0.98, p<0.001\right)$. 


\section{Discussion}

\section{0-2700 cal yr BP}

Carbon/nitrogen ratios at the base of cores 10 and 36 range from 16 to 27 , indicating the presence of terrestrial organic matter or nitrogen limitation in the lake (Meyers and Eadie, 1993; Healy and Hendzel, 1979). Calculated ages from both cores suggest this period lasted from at least 5100 to $4200 \mathrm{cal}$ yr BP (240-214 cm in core 36; $108-91 \mathrm{~cm}$ in core 10) (Table 3). The age control in the lower part of core 10 is poorer than in core 32 , but the similarity in $\mathrm{C} / \mathrm{N}$ trends in the two cores supports the calculated ages. A high flux of carbon at this time may result from lake-level lowering and resuspension of sediments from the lake margins, or from higher runoff and inwash of terrestrial organic matter. The former explanation is unlikely because productivity is low in shallow water at the margins of Kluane Lake. However, at a lower lake level, site 36 may have been closer to the shore and thus a depocenter of increased sedimentation of terrestrial organic matter (Tenzer et al., 1997). Wood fragments and stones below $219 \mathrm{~cm}$ in core 36 also suggest lower lake levels than today. Similarly, coarse sediment near the base of core 10 suggests a lower lake level than at present about 5000 cal yr BP. By 214 $\mathrm{cm}$ depth in core 36 and $91 \mathrm{~cm}$ depth in core $10, \mathrm{C} / \mathrm{N}$ ratios decrease to values characteristic of aquatic organic matter (6-10), suggesting an increase in lake level about 4200 cal yr BP. The increase probably was no greater than a few metres, because sediments of this age in core 08 are coarse and probably were deposited in shallow water. In addition, Cultus Bay and Grayling Lake did not exist at this time, suggesting that lake level was below $-14 \mathrm{~m}$. 


\section{0 to 1300 cal yr BP}

A step-shift increase in $\mathrm{C} / \mathrm{N}$ ratios, from 12 to 19 , occurs in core 36 about 2700 cal yr BP $(153 \mathrm{~cm})$ and remains high until $1300 \mathrm{cal}$ yr BP $(96 \mathrm{~cm})$. A similar step-shift increase, from 10 to 18 , occurs in core 10 at 3000 cal yr BP $(68 \mathrm{~cm})$ and remains high until $1350 \mathrm{cal}$ yr $\mathrm{BP}(37 \mathrm{~cm})$, when the ratio drops below 10 . The increase in $\mathrm{C} / \mathrm{N}$ ratio in core 10 may be due, in part, to loss of ammonia gas through degradation of the organic matter in the sediments. A correction based on the carbon excess places the $\mathrm{C} / \mathrm{N}$ ratio at about 18 , higher than in most algal sources but still within the range of terrestrial vegetation. Grain-size data from core 36 indicate a shoaling at $2700 \mathrm{cal} \mathrm{yr}$ BP $(153 \mathrm{~cm})$, followed by further shoaling at $1850 \mathrm{cal} \mathrm{yr} \mathrm{BP}(117 \mathrm{~cm})$. Sediment fingerprinting reported by Brahney et al. (2007) is consistent with these results and indicates a gradual reduction in Duke River sediments to the lake from 2700 to $1850 \mathrm{cal}$ yr BP $(153-117 \mathrm{~cm})$ and little or no contribution of sediment from Slims River at that time. The absence of a significant contribution from either of these large rivers is consistent with lake-level lowering. In addition, Duke River may have completely bypassed Kluane Lake between 1850 and $1300 \mathrm{cal}$ yr BP $(117-96 \mathrm{~cm})$ (Brahney et al., 2007). The decrease in water content between 68 and $53 \mathrm{~cm}$ in core 10 suggests an increase in mean grain size, consistent with a shoaling around 3000 to 2200 cal yr BP.

Core 08 is the shallowest core $(25 \mathrm{~m})$ and thus is likely to be most sensitive to lake level fluctuations. The presence of coarse sand in the core catcher suggests that the lake was at least $-20 \mathrm{~m}$ below current levels about 2400 years ago.

Paleoclimate data from this region indicate that the period from 2800 to $1300 \mathrm{cal}$ yr BP was colder and wetter than today (Anderson et al., 2005). Reduced or no inflow 
from the redirected Slims and Duke rivers would have kept Kluane Lake level low, while increased run-off from small streams could have contributed more terrestrial organic matter to the lake without significantly raising its level. This situation could explain the observed increases in $\% \mathrm{C}$ and $\mathrm{C} / \mathrm{N}$ during this period. The high carbon/nitrogen ratios are probably not due to organic degradation because $\mathrm{C}$ and $\mathrm{N}$ values are at their highest levels in core 36. More likely, anoxic conditions of the basin contributed to the preservation of organic material (Brahney et al., 2007). Anoxia is supported by the absence of the gastropod Valvata sincera sincera above $150 \mathrm{~cm}$ in core 36 and above 61 $\mathrm{cm}$ in core 10. This species lives at depths from $1 \mathrm{~m}$ to $>30 \mathrm{~m}$ and thus is not a useful direct indicator of lake level. It is, however, limited by food and oxygen availability. Magnetic susceptibility is relatively high between 218 and $195 \mathrm{~cm}$ in core 13, coincident with visible black laminae. This interval dates to 2200 to 1900 cal yr BP. The black laminae and what appear to be scattered sulfurized organic remains are likely responsible for the elevated magnetic susceptibility. The presence of coarse plant detritus in this interval may be due to shoaling.

Increases in $\% \mathrm{C}$ and $\% \mathrm{~N}$ from 2700 to $1300 \mathrm{cal} \mathrm{yr} \mathrm{BP} \mathrm{in} \mathrm{cores} 36$ and 10 cannot be explained by heightened productivity because $\delta^{13} \mathrm{C}$ decreases during this period. Heightened productivity would likely enrich $\delta^{13} \mathrm{C}$ through a more intense use of the available carbon pool. Instead, $\delta^{13} \mathrm{C}$ and $\% \mathrm{C}$ are negatively correlated in units 3,4 , and 5 of core $36\left(r^{2}=0.65, p<0.001\right)$; the two are also negatively correlated in core $10\left(r^{2}=\right.$ $0.77, p<0.001)$.

$\delta^{13} \mathrm{C}$ is in the -24 to $-25 \%$ range in units 1,2 , and 4 of core 36 . A small step-shift to more depleted values in unit 3 could be attributed to selective degradation of 
isotopically heavy proteins and carbohydrates. This explanation, however, is doubtful in the case of Kluane Lake because $\% \mathrm{C}$ and $\% \mathrm{~N}$ values during this period are the highest in the core and scatter plots do not indicate any elemental excess. If we assume that the high $\mathrm{C} / \mathrm{N}$ ratios in unit 3 result from terrestrial organic matter and not nitrogen-limited algae, the $\delta^{13} \mathrm{C}$ and $\delta^{15} \mathrm{~N}$ values reflect the isotopic composition of terrestrial plants. The aquatic organic matter is then slightly enriched in $\delta^{13} \mathrm{C}$ relative to the terrestrial vegetation. $\delta^{13} \mathrm{C}$ from aquatic organic matter and from plants in the same watershed is generally indistinguishable because the aquatic and terrestrial plants produce organic matter from the same atmospheric $\mathrm{CO}_{2}$ source. A difference requires a dissolved inorganic carbon source that is not in equilibrium with the atmosphere. Increased productivity may shift the $\delta^{13} \mathrm{C}$ to higher values through intense use of the available carbon pool, but productivity in Kluane Lake probably was never high. Disequilibrium from the atmosphere could stem from enriched dissolved inorganic carbon supplied from the watershed, leaving the terrestrial and aquatic organic material with different signatures.

A drop in $\delta^{15} \mathrm{~N}$ within unit 3 in core 36 is consistent with a terrestrial organic matter source, although the shift to values as high as $3 \%$ within this interval probably does not reflect terrestrial organic matter. The value is not spurious as duplicates were run for this interval and $\delta^{15} \mathrm{~N}$ values increase and decrease gradually. The high $\delta^{15} \mathrm{~N}$ values may reflect terrestrial organic matter that has been modified by lacustrine processes. Under mildly reducing conditions, $\delta^{15} \mathrm{~N}$ can increase through the release of isotopically light $\mathrm{N}_{2}$ gases during organic degradation (Talbot, 2001). The $\delta^{15} \mathrm{~N}$ peak precedes peaks in elements that indicate highly reducing conditions (Brahney et al., 2007). 
Although the evidence suggests lake-level lowering at this time, the abruptness of the $\mathrm{C} / \mathrm{N}$ shift is perplexing. Nitrogen limitation can, however, raise the $\mathrm{C} / \mathrm{N}$ ratio to within the range of terrestrial organic matter. Reduced nitrogen input into the lake may have occurred due to permafrost expansion in the watershed. The area is presently within the zone of discontinuous permafrost. Permafrost was likely more widespread 2700-1300 cal yr ago when climate was colder than today. Under these circumstances, nitrogen may have been less available due to slow nitrogen mineralization (Heilman, 1966; Bonan, 1990). Permafrost can also contribute dissolved organic carbon to the lake by focusing flow though shallow soil layers.

If we assume that the organic proxies during this period were controlled by nitrogen-limited aquatic organic matter, we must still explain the step-like isotopic shift in dissolved inorganic carbon in the lake water. Carbon dioxide solubility increases in colder water. With more available $\mathrm{CO}_{2}$, isotopic discrimination between the inorganic carbon and biotic carbon would decrease due to the greater availability of the lighter isotope of carbon. In addition, isotopically light carbon from the watershed could have reduced the overall isotopic values of the inorganic carbon in the lake. Respired carbon from organic soils would be isotopically lighter than dissolved inorganic carbon supplied from the atmosphere. The sudden isotopic shift is thus more likely the result of a change in the extent of permafrost in the watershed than a fall in lake level, which would probably take more time. Geochemical evidence in core 36 suggests that permafrost may have expanded at this time (Brahney et al., 2007). 


\section{0-300 cal yr BP}

Environmental proxies in unit 2 of core 36 are consistent with rising lake level about $1300 \mathrm{yr}$ ago. Specifically, $\delta^{13} \mathrm{C}$ and $\delta^{15} \mathrm{~N}$ increase, and $\mathrm{C} / \mathrm{N}, \%$ organics, and grain size decrease. Scattered fragments of wood were found in core 13 from its base to 160 $\mathrm{cm}$, which dates to about $1450 \mathrm{cal} \mathrm{yr} \mathrm{BP}$, suggesting that the lake rose on or after this time. Brahney et al. (2007) concluded that Duke River began to flow into the lake at about this time. Sedimentation rates in the northern part of the lake are higher than in the southern part from 1200 to 300 cal yr BP, consistent with an important northerly sediment source.

Sediment in core 08 begins to fine at $34 \mathrm{~cm}$, suggesting a deepening of the lake about 900 cal yr BP, after deposition of the White River tephra. A similar change occurs in core 36 , but before deposition of the tephra, whereas the change in core 10 is almost coincident with tephra deposition. The diachronous nature of the contact is due to the different depths of the cores. The water depth at site 08 is $25 \mathrm{~m}$, which is $10 \mathrm{~m}$ less than at sites 36 and 10. Because the transgression was diachronous, silt began to accumulate at site 08 after sites 36 and 10 .

Density and water contents change in two steps in core 08. A small shift to lower densities and higher water content occurs about 900 cal yr BP $(34 \mathrm{~cm})$. A greater shift in the same direction occurs at the contact with unit $5(16 \mathrm{~cm}), \mathrm{ca} .300 \mathrm{cal} \mathrm{yr}$ BP. The data suggest a gradual deepening of the lake, followed by more substantial deepening when the modern Slims River became established.

Grain size in core 23 decreases from $130 \mathrm{~cm}$ to the top of the core. The change is accompanied by an increase in water content and a decrease in density. These changes 
probably reflect deepening of the lake. Unfortunately, surface sediment is missing from this core, thus the timing of the change cannot be precisely determined. The White River tephra, however, lies above $130 \mathrm{~cm}$. Assuming the same sedimentation rate as at nearby core site 21 , the $130-\mathrm{cm}$ level dates to $1300 \mathrm{cal} \mathrm{yr} \mathrm{BP}$.

\section{0 cal yr BP - present}

Grain size decreases in the upper unit of cores 36,10 , and 08 , suggesting a further increase in lake level. No decrease in grain size is evident in the upper part of core 13, but it is the deepest core and thus least sensitive to changes in lake level. The upper unit in cores 36,10 , and 08 also shows an increase in water content and, in the case of cores 36 and 10 , a decrease in $\mathrm{C} / \mathrm{N}$.

$\delta^{13} \mathrm{C}$ and $\mathrm{C} / \mathrm{N}$ increase in tandem $\left(r^{2}=0.81, p<0.001\right)$ in the upper unit of core 36 , perhaps due to the contributions of DIC from carbonate in sediment in the Slims River watershed and carbon from $\mathrm{C}_{4}$ plants growing on the Slims River delta. The close correlation between $\delta^{13} \mathrm{C}$ and $\mathrm{C} / \mathrm{N}$ suggests that peaks in both may be related to terrestrial plant matter. The low correlation between $\% \mathrm{C}$ and $\mathrm{N}$ may, in turn, reflect derivation from a mixture of aquatic and terrestrial plants, which is not surprising given that Slims River was newly established and lake level was rising. Rising waters inundated vegetated land, washing terrestrial organic detritus into the lake. Wood fragments are abundant at the bottom of the upper unit in both cores 10 and $36 . \delta^{13} \mathrm{C}$ values are high, around $-17 \%$, and are nearer those of $\mathrm{C}_{4}$ plants than $\mathrm{C}_{3}$ plants. $\mathrm{C}_{3}$ plants incorporate carbon into their biomass using the Calvin pathway. Both $\mathrm{C}_{4}$ and $\mathrm{C}_{3}$ plants preferentially take in ${ }^{12} \mathrm{C}$, with an isotopic discrimination of $-21 \%$ from the dissolved inorganic carbon source in $\mathrm{C}_{3}$ plants, giving an average isotopic value of $-28 \%$. Provided both sources of carbon are in 
equilibrium with atmospheric $\delta^{13} \mathrm{C}$ at $-7 \%, \mathrm{C}_{4}$ plants use the Hatch-Slack pathway, which causes a 7\% discrimination and gives these plants an average isotopic value of 14\%o (O'Leary, 1988). The measured $\delta^{13} \mathrm{C}$ values of about $-17 \%$ could represent a mixture of the two plant types. $\mathrm{C}_{4}$ plants are rare at this latitude, but several species of halophytes use the $\mathrm{C}_{4}$ pathway. Some of the plants living on the Slims River delta and floodplain are halophytes and could be the source of the isotopic shift in the upper unit of cores 10 and 36. Unfortunately, no specific metabolic information is available for the species that live on the Slims delta.

\section{Short-term changes in lake level over the past 1000 years}

Sediments at the base of core 26 from Cultus Bay record a change from terrestrial to lacustrine conditions. Wood fragments from the base of the core yielded an age of 1180 $\pm 40{ }^{14} \mathrm{C}$ yr BP $(1180-980$ cal yr BP). The core was collected in $14 \mathrm{~m}$ of water, thus Kluane Lake rose above $-14 \mathrm{~m}$ at that time. The high $\mathrm{C} / \mathrm{N}$ values near the base of core 26 record the transgression of the Cultus Lake basin. Similarly, Grayling Lake sediments were deposited on a buried soil at $-12 \mathrm{~m}$ after $1310 \pm 40{ }^{14} \mathrm{C}$ yr BP $(1300-1170 \mathrm{cal}$ yr BP).

The brief $+12 \mathrm{~m}$ high stand of Kluane Lake is clearly visible in unit 2 of both cores. Increases in $\mathrm{C} / \mathrm{N}$ and magnetic susceptibility reflect in-washing of terrestrial organic matter from the surrounding slopes. An increase in $\delta^{13} \mathrm{C}$ at this time is consistent with the enrichment in the main lake basin after inception of Slims River.

Similar changes in sediment type are observed in core 26 at 470-410 cal yr BP (73-67 cm) and 200-190 cal yr BP (40-37 cm), and in core 31 at 810-560 cal yr BP (96$89 \mathrm{~cm})$ and ca. $140 \mathrm{cal} \mathrm{yr} \mathrm{BP}(32 \mathrm{~cm})$. These intervals are characterized by elevated 
magnetic susceptibility, density, and $\delta^{13} \mathrm{C}$, and by lower organic matter and water content, and may record short-lived rises in water level (Brahney et al., 2007).

$\mathrm{C} / \mathrm{N}$ values near the top of core 26 suggest a return to aquatic organic sedimentation after the high stand. Percent $\mathrm{C}, \% \mathrm{~N}$, and $\delta^{15} \mathrm{~N}$ reach their highest values near the top of core 26, possibly reflecting an increase in productivity from maturation of Cultus Bay. Because aquatic organisms preferentially use the lighter isotope of nitrogen, an increase in $\delta^{15} \mathrm{~N}$ could occur through the progressive removal and burial of organic matter in sediments. An increase in both productivity and $\delta^{15} \mathrm{~N}$ could also be related to spawning salmon, which first entered the lake about $300 \mathrm{cal}$ yr ago, when the northern outlet was established.

\section{Summary of level changes over the past 5000 years}

Fluctuations in the level and areal extent of Kluane Lake during the late Holocene are the result of changes in Slims and Duke River inflow, which in turn are linked to glacier and climate change. To summarize, in sequence (Figure 10):

Kluane Lake has been higher than about $-27 \mathrm{~m}$ for the past 5000 years, because lacustrine conditions have persisted throughout this period at core site 36 . Sand occurs on the modern lake floor to a depth of $5 \mathrm{~m}$; below that, it grades into silt at $10 \mathrm{~m}$ depth (Rampton and Shearer, 1978). Silty sediments dominate core 36, which was collected from a depth of $36 \mathrm{~m}$, thus we infer that a minimum of $10 \mathrm{~m}$ of water continuously covered that site throughout the time span of the core. The presence of fine sand near the base of core 10 suggests that lake level may have been between -27 and $-22 \mathrm{~m}$ about 5000 cal yr BP. High C/N ratios near the base of cores 10 and 36, and the up-core decrease in grain size in core 10 further suggest that lake level was lower than $-20 \mathrm{~m}$ and 
rising around $4000 \mathrm{cal}$ yr BP. The rise probably was no more than a few metres and the lake was no higher than $-14 \mathrm{~m}$ at that time, a constraint imposed by cores 08,31 , and 26 .

A fall in lake level between 2900 and $2700 \mathrm{cal}$ yr BP is suggested by an increase in grain size and $\mathrm{C} / \mathrm{N}$ ratios in core 36 and by the increase in $\mathrm{C} / \mathrm{N}$ ratios and dry density in core 10. Again, the change in lake level probably was not more than a few meters. Core 08 indicates that lake level may have been between -20 and $-25 \mathrm{~m}$, as sand was deposited at this site $2500 \mathrm{cal}$ yr BP. Data presented by Brahney et al. (2007) suggest that this lowering of the lake is related to a reduction or elimination of flow of Duke River into Kluane Lake. Further lake level lowering and the development of anoxia about 2000 cal yr BP are suggested by the increase in grain size in core 36 and disappearance of Valvata sincera sincera in cores 10 and 36 . However, the lake did not fall below $-27 \mathrm{~m}$ 2000 cal yr BP because lacustrine sedimentation continued at core site 36 . This result is inconsistent with Rampton and Shearer's (1978) interpretation of the ca. 2000-year-old peat layer they found at $-50 \mathrm{~m}$ in a core near the south end of Kluane Lake. It is possible, however, that the peat layer is not terrestrial or, alternatively, that it slumped to the core site from a shallower depth.

Cores $08,26,31,10,36,13$, and 23 provide evidence for a rise in lake and groundwater levels between 1300 and $900 \mathrm{cal}$ yr BP. Increases in $\delta^{13} \mathrm{C}$ and $\delta^{15} \mathrm{~N}$, and decreases in $\mathrm{C} / \mathrm{N}, \%$ organics, and grain size in unit 2 of core 36 are consistent with lake deepening. The Grayling Lake and Cultus Bay cores show that the lake rose above -14 m about 1300 to 1200 cal yr BP. Geochemical data presented by Brahney et al. (2007) indicate that Duke River began to flow into Kluane Lake about 1300 cal yr BP and continued for several centuries, causing the lake to rise. Inflow of Duke River water 
during this period is consistent with sedimentation rates in cores at the time of deposition of White River tephra. Sedimentation rates are higher at core site 21 in the central part of the lake and nearer Duke River than at core sites farther south. The transgression may have been slow because the Duke River sediment signature appears at different times at the core sites, depending on their depths. Rampton and Shearer (1978) did not find tephra in a core taken at $12 \mathrm{~m}$ depth, suggesting that the lake may have been at or below $-12 \mathrm{~m}$ about 1150 cal yr BP. By AD 1650, however, the lake had risen to its present level due to diversion of Kaskawulsh Glacier meltwater into Kluane Lake (Clague et al., 2006). The influx of meltwater is clearly recorded by sediments of Slims River origin in all cores taken from the southern part of the lake. By about AD 1700, Kluane Lake achieved its Holocene high stand of $+12 \mathrm{~m}$ and soon thereafter began to fall as its new, northern outlet was incised. The short-lived nature of the high stand is indicated by the thin, laminated, inorganic silt unit overlying shallow-water organic-rich sediments in the Grayling Lake and Cultus Bay cores.

\section{Evidence for a pre-5000 cal yr BP high stand of Kluane Lake}

Dense laminated silt underlies the soil in the Grayling Lake core. The silt must have been deposited during a previous high-stand of Kluane Lake. This early lake is also suggested by the sub-bottom acoustic record from Brooks Arm. The acoustic record shows laminated sediments beneath $\sim 1 \mathrm{~m}$ of modern lacustrine sediments (R. Gilbert, personal communication, 2005). A conspicuous acoustic reflector separates the two units and probably represents a prolonged period of non-deposition. Brooks Arm is shallow, 5 to $10 \mathrm{~m}$, and was not flooded until the recent rise in lake level. The sediments above the reflector were deposited during the past 350 years. The sediments below the reflector 
must be much older because, except for the past several hundred years, Kluane Lake has been below $-5 \mathrm{~m}$ for at least the past 4800 years.

Fluctuations in lake level recorded in this study show that Kluane Lake is sensitive to climate-related drainage changes. The lake was well below its modern datum prior to the recent diversion of the Slims River, thus a future diversion of this river due to retreat of Kaskawulsh Glacier probably would lower the lake below its current outlet. The study further illustrates that relatively small changes in climate can have large effects on lake hydrology.

\section{Conclusion}

Kluane Lake has experienced complex and rapid fluctuations in its level and areal extent over the past 5000 years, primarily due to changes in input of waters from Slims and Duke rivers. From 5000 to 4200 cal yr BP, the surface of Kluane Lake was 22 to $27 \mathrm{~m}$ lower than today. Lake level increased a few metres around 4200 cal yr BP and may have remained at that level until $2700 \mathrm{cal} \mathrm{yr} \mathrm{BP}$, when it fell several meters. A further small decrease in water level may have occurred around $1850 \mathrm{cal}$ yr BP. About $1300 \mathrm{cal}$ yr BP, the level of the lake rose from -25 to $-13 \mathrm{~m}$ as a result of the diversion or increased flow of Duke River into Kluane Lake. The level of Kluane Lake level rapidly rose to $+12 \mathrm{~m}$ about 300 cal yr BP when Slims River began to flow into the lake. After the establishment of the northerly drainage route, the lake rapidly fell to near its present level, and the lake has fluctuated within $2 \mathrm{~m}$ of the present datum over the past 150-200 years. 


\section{Acknowledgements}

We thank Melanie Grubb, Robert Gilbert, and Rob Price for valuable field and

laboratory assistance. Research funding was provided by the Natural Science and

Engineering Research Council of Canada (Postgraduate Scholarship to Brahney;

Discovery Grants to John Clague, Brian Menounos, and Tom Edwards), the Geological Society of America, and Northern Scientific Training Program. 


\section{References}

Anderson, L., Abbott, M.B., Finney, B.P., Burns, S.J., 2005. Regional atmospheric circulation change in the North Pacific during the Holocene inferred from lacustrine carbonate oxygen isotopes, Yukon Territory, Canada. Quaternary Research 64, 21-35.

Bonan, G.B., 1990. Carbon and nitrogen cycling in North American boreal forests. I. Litter quality and thermal regime effects in interior Alaska. Biogeochemistry 10, $1-28$

Borns, H.W, Jr., Goldthwait, R.P., 1966. Late-Pleistocene fluctuations of Kaskawulsh Glacier, southwestern Yukon Territory, Canada. American Journal of Science 264, 600-619.

Bostock, H.S., 1969. Kluane Lake, Yukon Territory; its drainage and allied problems. Geological Survey of Canada Paper 69-28.

Brahney, J., Clague, J., Menounos, B., Edwards, T., 2007. Geochemical reconstruction of late Holocene drainage and mixing in Kluane Lake, Yukon Territory, Canada. Journal of Paleolimnology, doi:10.1007/s10933-007-9177-z.

Clague, J.J., 1981. Landslides at the south end of Kluane Lake, Yukon Territory. Canadian Journal of Earth Sciences 18, 959-971.

Clague, J.J., Evans, S.G., Rampton, V.N., Woodsworth, G.J., 1995. Improved age estimates for the White River and Bridge River tephras, western Canada. Canadian Journal of Earth Sciences 32, 1172-1179. 
Clague, J.J., Luckman, B.H., Van Dorp, R.D., Gilbert, R., Froese, D., Jensen, B.J.L., Reyes, A.V., 2006. Rapid changes in the level of Kluane Lake in Yukon Territory over the last millennium. Quaternary Research 66, 342-355.

Denton, G.H., Karlén, W., 1977. Holocene glacial and tree-line variations in the White River valley and Skolai Pass, Alaska and Yukon Territory. Quaternary Research 7, 63-111.

Denton, G.H., Stuiver, M., 1966. Neoglacial chronology, northeastern St. Elias Mountains, Canada. American Journal of Science 264, 577-599.

Gilbert, R., Desloges, J.R. 1987. Sediments of ice-dammed, self-draining Ape Lake, British Columbia. Canadian Journal of Earth Sciences 24, 1735-1747.

Healey, F.P., Hendzel, L.L., 1979. Physiological indicators of nutrient deficiency in lake phytoplankton. Canadian Journal of Fisheries and Aquatic Sciences 37, 442-453.

Hecky, R.E., Campbell, P., Hendzel, L.L., 1993. The stoichiometry of carbon, nitrogen, and phosphorus in particulate matter of lakes and ocean. Limnology and Oceanography 38, 709-724.

Heilman, P.E., 1966. Change in distribution and availability of nitrogen with forest succession on north slopes in interior Alaska. Ecology 47, 825- 831.

Menounos, B., 1997. The water content of lake sediments and its relationship to other physical parameters: An alpine case study. The Holocene 7, 207-212. 
Meyers, P.A., Eadie, B.J., 1993. Sources, degradation and recycling of organic matter associated with sinking particles in Lake Michigan. Organic Geochemistry 20, 4756.

Meyers, P.A., Teranes, J.L. 2001. Sediment organic matter. In: Last, W.M., Smol, J.P. (Eds.), Tracking Environmental Change Using Lake Sediments. Volume 2: Physical and Geochemical Techniques. Kluwer Academic Publishers, Dordrecht, The Netherlands, pp. 239-269.

Natural Resources Canada., 2003. The Atlas of Canada: Facts about Canada: Lakes. http://atlas.gc.ca/site/english/learningresources/facts/lakes.html\#yukon (accessed January 2005).

O'Leary, M.H., 1988. Carbon isotopes in photosynthesis. Bioscience 38, 328-336.

Rampton, V.N., Shearer, J.M., 1978. The geology and limnology of Kluane Lake, Yukon Territory, I Preliminary assessment. Terrain Analysis and Mapping Services Ltd., Stittsville, ON.

Talbot, M.R. 2001., Nitrogen isotopes in palaeolimnology. In: Last, W.M., Smol, J.P. (Eds.), Tracking Environmental Change Using Lake Sediments. Volume 2: Physical and Geochemical Techniques. Kluwer Academic Publishers, Dordrecht, The Netherlands, pp. 401-439.

Tenzer, G.E., Meyers, P.A., Knoop, P., 1997. Sources and distribution of organic and carbonate carbon in sediments of Pyramid Lake, Nevada. Journal of Sedimentary Research 67, 884-890. 
Table 1. Description of sediment cores.

\begin{tabular}{|c|c|c|c|c|c|}
\hline Core \# & $\begin{array}{l}\text { Depth } \\
(\mathrm{m})\end{array}$ & $\begin{array}{l}\text { Core } \\
\text { length } \\
(\mathrm{cm})\end{array}$ & $\begin{array}{l}\text { Unit and depth } \\
(\mathrm{cm})\end{array}$ & Sediment description & Munsell colour \\
\hline \multirow[t]{4}{*}{36} & \multirow[t]{4}{*}{36} & \multirow[t]{4}{*}{240} & $5(65-0)$ & $\begin{array}{l}\text { Laminated light olive-grey clayey silt; laminae are } 1-5 \mathrm{~mm} \\
\text { thick. Contact with unit } 4 \text { is abrupt. }\end{array}$ & $5 Y 6 / 1-5 Y 6 / 2$ \\
\hline & & & $4(96-66)$ & $\begin{array}{l}\text { Massive brown fine sand and silt with few fine to medium } \\
\text { grained sand laminae. White River tephra at } 88 \mathrm{~cm} \text {. Unit } 4 \\
\text { interfingers with unit } 3 \text {. }\end{array}$ & 7.5YR4/1-7.5YR4/2 \\
\hline & & & $2(220-154)$ & $\begin{array}{l}\text { Light grey silt and fine to very fine sand with few black } \\
\text { laminae. Contacts with units } 1 \text { and } 3 \text { gradational. }\end{array}$ & $5 Y 6 / 1-5 Y 5 / 1$ \\
\hline & & & $1(240-221)$ & $\begin{array}{l}\text { Light grey silt and fine to very fine sand with numerous black } \\
\text { laminae }(<1 \mathrm{~mm}) \text {. Valvata sincera sincera present from base of } \\
\text { core to } 150 \mathrm{~cm} \text {. Pebbles present from base of the core to } 197 \\
\mathrm{~cm} \text {. }\end{array}$ & $5 Y 6 / 1-5 Y 5 / 1$ \\
\hline \multirow{5}{*}{10} & \multirow{5}{*}{33} & \multirow{5}{*}{108} & $4(33-19)$ & Brown silt with orange laminae. & $2.5 \mathrm{Y} 4 / 2$ \\
\hline & & & $35-34$ & White River tephra. & \\
\hline & & & $3(68-36)$ & Laminated light grey silt. & $5 Y 4 / 1$ \\
\hline & & & $2(91-69)$ & Laminated light grey silt. & $5 Y 4 / 1$ \\
\hline & & & $1(108-92)$ & $\begin{array}{l}\text { Laminated light grey silt; overal upward fining from unit } 1 \text { to } \\
\text { 3. Contacts between all units gradational. }\end{array}$ & $5 Y 4 / 1$ \\
\hline \multirow[t]{3}{*}{8} & \multirow[t]{3}{*}{25} & \multirow[t]{3}{*}{63} & $5(16-0)$ & $\begin{array}{l}\text { Laminated olive grey silt with pale yellow beds }(1-1.5 \mathrm{~cm}) \text {. } \\
\text { Abruptly overlies unit } 3 .\end{array}$ & $5 Y 5 / 2-5 Y 5 / 3$ \\
\hline & & & $4(33-17)$ & $\begin{array}{l}\text { Brown laminated fine sand with orange laminae. Interfingers } \\
\text { with unit } 2\end{array}$ & $2.5 \mathrm{Y} 5 / 1-2.5 \mathrm{Y} 3 / 3,10 \mathrm{YR} 5 / 6$ \\
\hline & & & $3(63-34)$ & $\begin{array}{l}\text { Laminated grey fine to medium sand. White River tephra at } 39 \\
\mathrm{~cm} .\end{array}$ & $10 Y 2.5 / 1$ \\
\hline \multirow[t]{5}{*}{26} & \multirow[t]{5}{*}{14} & \multirow[t]{5}{*}{180} & $5(41-0)$ & $\begin{array}{l}\text { Weakly laminated light grey silt with scattered black spots and } \\
\text { streaks. Distinctive organic-poor bed at } 39-37 \mathrm{~cm} \text {. }\end{array}$ & $5 Y 2.51-5 Y 4 / 1$ \\
\hline & & & $4(52-42)$ & 22-25 couplets of light grey silt. & $5 Y 5 / 1$ \\
\hline & & & $3(139-53)$ & $\begin{array}{l}\text { Grey silt with fine sand laminae. Black streaks near the base of } \\
\text { unit. Roots in growth position at } 133 \mathrm{~cm} .\end{array}$ & $5 Y 2.5 / 1-5 Y 3 / 1)$ \\
\hline & & & $2(155-140)$ & $\begin{array}{l}\text { Fine to medium sand with scattered plant macrofossils. Contact } \\
\text { with unit } 1 \text { is sharp. }\end{array}$ & $5 \mathrm{Y} 3 / 1$ \\
\hline & & & $1(180-156)$ & Coarse sand with plant detritus at $177 \mathrm{~cm}$. & $5 Y 2.5 / 1$ \\
\hline
\end{tabular}


Table 1. Con't.

\begin{tabular}{|c|c|c|c|c|c|}
\hline Core \# & Depth (m) & $\begin{array}{l}\text { Core length } \\
(\mathrm{cm})\end{array}$ & $\begin{array}{l}\text { Unit } \\
\text { divisions } \\
(\mathrm{cm})\end{array}$ & Sediment description & Munsell \\
\hline \multirow[t]{5}{*}{31} & 12 & 167 & $5(49-0)$ & Weakly laminated dark grey silt. Contact with unit 4 is sharp. & \\
\hline & & & $4(75-50)$ & Light grey silt. Contact with unit 3 is gradational. & \\
\hline & & & $3(97-76)$ & $\begin{array}{l}\text { Organic rich poorly laminatd silt containing many wood } \\
\text { fragments. }\end{array}$ & \\
\hline & & & $2(105-98)$ & $\begin{array}{l}\text { Soil containing roots in growth position, fungal hyphae, root } \\
\text { casts, and root oxidation rings. }\end{array}$ & \\
\hline & & & $1(167-106)$ & Dense lamiinated light grey silt. & $5 Y 4 / 1$ \\
\hline \multirow[t]{2}{*}{21} & 33.5 & 250 & $2(24-0)$ & Laminated silt of bright colorus from orange to grey. & $\begin{array}{l}\text { 10YR5/4 10RY3/2, } \\
5 \mathrm{Y} 5 / 1,2.5 \mathrm{Y} 5 / 4\end{array}$ \\
\hline & & & $1(250-25)$ & $\begin{array}{l}\text { Massive to weakly laminated grey silt with fine sand laminae. } \\
\text { Numerous fine sand event laminae occur from } 190-155 \mathrm{~cm} \text {. } \\
\text { Whiter River tephra occurs at } 223 \mathrm{~cm} \text {. }\end{array}$ & $5 \mathrm{Y} 3 / 1$ \\
\hline \multirow[t]{2}{*}{19} & 32 & 244 & & Massive grey silt with scattered black and sulfurized organics. & $2.5 \mathrm{Y} 4 / 1-2.5 \mathrm{Y} 3 / 1$ \\
\hline & & & & White River tephra occurs at $130 \mathrm{~cm}$. & \\
\hline 23 & 38.5 & 292 & & $\begin{array}{l}\text { Massive to weakly laminated grey silt with scattered black and } \\
\text { sulfurized organics. White River tephra occurs at } 31 \mathrm{~cm}\end{array}$ & $5 \mathrm{Y} 4 / 1-5 \mathrm{Y} 3 / 1$ \\
\hline
\end{tabular}

Table 2. Radiocarbon ages from Kluane Lake cores.

\begin{tabular}{|c|c|c|c|c|}
\hline${ }^{14} \mathrm{C}$ age $(\mathrm{yr} \mathrm{BP}){ }^{1}$ & Laboratory no. & $\begin{array}{l}\text { Core no. and sample } \\
\text { depth }\end{array}$ & Material & $\begin{array}{l}\text { Calendar age } \\
\text { (cal yr BP) }\end{array}$ \\
\hline $1660 \pm 40$ & Beta - 200708 & $08(50.5 \mathrm{~cm})$ & wood & $1690-1660$ and \\
\hline $1180 \pm 40$ & Beta - 200709 & $26(177 \mathrm{~cm})$ & wood & $1180-980$ \\
\hline $1310 \pm 40$ & Beta - 200710 & $31(103 \mathrm{~cm})$ & wood & $1300-1170$ \\
\hline $1180 \pm 40$ & Beta - 213014 & $26(139 \mathrm{~cm})$ & wood & $1180-980$ \\
\hline $3910 \pm 80$ & TO - 12468 & $36(219 \mathrm{~cm})$ & $\begin{array}{l}\text { spruce needle } \\
\text { and twig }\end{array}$ & $4570-4090$ \\
\hline
\end{tabular}

\footnotetext{
${ }^{1}$ Radiocarbon laboratory: Beta-Beta Analytic Inc.; TO - IsoTrace Radiocarbon Laboratory (University of Toronto).

${ }^{2}$ Determined from the calibration data set IntCa198 (Stuiver et al. 1998); calibrated age ranges are reported as $\pm 2 \sigma$.
} 
Table 3. Calibrated and calculated sediment ages.

\begin{tabular}{|c|c|c|c|c|c|}
\hline Core \# & Unit $^{1}$ & $\begin{array}{l}\text { Age control } \\
\text { depth }(\mathrm{cm})\end{array}$ & $\begin{array}{l}\text { Calibrated age } \\
\text { ( cal yr BP) }\end{array}$ & $\begin{array}{l}\text { Sedimentation } \\
\text { rate }(\mathrm{cm} / \mathrm{yr})\end{array}$ & $\begin{array}{l}\text { Age estimate (cal } \\
\text { yr BP) }\end{array}$ \\
\hline \multirow[t]{7}{*}{36} & 5 (b) & 65 & 300 & 0.22 & \\
\hline & $4(t)$ & 96 & & & 1350 \\
\hline & & 88 & 1147 & 0.03 & \\
\hline & & 117 & & & 1850 \\
\hline & 3 (b) & 153 & & & 2700 \\
\hline & & 219 & 4330 & 0.04 & \\
\hline & 1 (b) & 240 & & & 4800 \\
\hline \multirow[t]{7}{*}{$\overline{10}$} & 5 (b) & 18 & 300 & 0.06 & \\
\hline & & 34 & 1147 & 0.02 & \\
\hline & $3(\mathrm{t})$ & 36 & & & 1300 \\
\hline & & 53 & & & 2200 \\
\hline & 3 (b) & 68 & & & 3000 \\
\hline & 2 (b) & 91 & & & 4200 \\
\hline & 1 (b) & 108 & & & 5100 \\
\hline \multirow[t]{5}{*}{$\overline{8}$} & 5 (b) & 16 & 300 & 0.05 & \\
\hline & $3(\mathrm{t})$ & 34 & & & 900 \\
\hline & & 39 & 1147 & 0.03 & \\
\hline & & 50.5 & 1595 & 0.03 & \\
\hline & Core catcher & 70 & & & 2400 \\
\hline \multirow[t]{2}{*}{13} & & 80 & 300 & 0.3 & \\
\hline & $3(t)$ & 140 & 1147 & 0.07 & \\
\hline
\end{tabular}

${ }^{1}$ Age control at base (b) or top (t) of specified unit. 
Table 4. Calculated sedimentation rates.

\begin{tabular}{llllllllllllllll}
\hline & \multicolumn{3}{c}{ Core 08 } & \multicolumn{2}{c}{ Core 10 } & \multicolumn{2}{c}{ Core 13 } & \multicolumn{2}{c}{ Core 36 } & \multicolumn{2}{c}{ Core 21 } & \multicolumn{2}{c}{ Core 26 } & \multicolumn{2}{c}{ Core 31 } \\
& $\mathrm{cm} / \mathrm{yr}$ & $\mathrm{g} / \mathrm{cm}^{2} . \mathrm{yr}$ & $\mathrm{cm} / \mathrm{yr}$ & $\mathrm{g} / \mathrm{cm}^{2} . \mathrm{yr}$ & $\mathrm{cm} / \mathrm{yr}$ & $\mathrm{g} / \mathrm{cm}^{2} . \mathrm{yr}$ & $\mathrm{cm} / \mathrm{yr}$ & $\mathrm{g} / \mathrm{cm}^{2} . \mathrm{yr}$ & $\mathrm{cm} / \mathrm{yr}$ & $\mathrm{g} / \mathrm{cm}^{2} . \mathrm{yr}$ & $\mathrm{cm} / \mathrm{yr}$ & $\mathrm{g} / \mathrm{cm}^{2} . \mathrm{yr}$ & $\mathrm{cm} / \mathrm{yr}$ & $\mathrm{g} / \mathrm{cm}^{2} . \mathrm{yr}$ \\
\hline Unit 5 & 0.05 & 0.045 & 0.06 & 0.048 & 0.27 & 0.21 & 0.22 & 0.24 & 0.19 & 0.15 & & & 0.23 & 0.21 \\
Unit 4 & 0.03 & 0.041 & 0.02 & 0.019 & 0.07 & 0.04 & 0.03 & 0.03 & 0.19 & 0.15 & 0.25 & 0.2 & 0.27 & 0.25 \\
Unit 3 & 0.03 & 0.043 & 0.02 & 0.016 & 0.07 & 0.05 & 0.04 & 0.04 & 0.19 & 0.15 & 0.13 & 0.11 & 0.03 & 0.03 \\
Unit 2 & & & 0.02 & 0.019 & & & 0.04 & 0.04 & 0.19 & 0.15 & & & & \\
Unit 1 & & & 0.02 & 0.024 & & & 0.04 & 0.04 & 0.19 & 0.15 & & & & \\
\hline
\end{tabular}




\section{Figure Captions}

Figure 1. Map of Kluane Lake and surrounding region (modified from Clague et al. 2006, with permission from Elsevier).

Figure 2. Core locations in Kluane Lake, Cultus Bay, and Grayling Lake (modified from Clague et al. 2006, with permission from Elsevier).

Figure 3. Lithostratigraphy and correlation of Kluane Lake cores.

Figure 4. Lithostratigraphy of Grayling Lake and Cultus Bay cores.

Figure 5. Bulk physical and organic properties and stratigraphy of core 36. Calculated ages are indicated in grey.

Figure 6. Scatter plot of $\% \mathrm{C}$ vs. $\% \mathrm{~N}$ in core 10.

Figure 7. Bulk physical and organic properties and stratigraphy of core 10 . The high magnetic susceptibility of the White River tephra obscures variations through the rest of the core. For this reason, magnetic susceptibility is displayed on the right with the tephra removed. Calculated ages are indicated in grey. 
Figure 8. Bulk physical properties and stratigraphy of core 08 and 13. Calculated ages are indicated in grey.

Figure 9. Bulk physical and organic properties and stratigraphy of cores 26 and 31.

Figure 10. Inferred Kluane Lake level fluctuations over the past 5000 years. The grey band represents uncertainty in lake level estimates. 